\title{
METODY DZIAŁAŃ JANA III SOBIESKIEGO W POLITYCE WEWNĘTRZNEJ DO ROKU 1679
}

\author{
Jarosław Stolicki ${ }^{\text {http://orcid.org/0000-0002-8357-81101 }}$ \\ Uniwersytet Jagielloński w Krakowie
}

\section{ABSTRACT \\ JOHN III SOBIESKI'S DOMESTIC POLICIES BEFORE 1679}

John III Sobieski's domestic politics was mostly subordinated to his foreign policy objectives. The king's post-election course of action was strongly influenced by his past experiences. He deferred the coronation until a more favourable moment, although the political benefits of that decision failed to materialize. The new king's politics was quite cautious. He did not put forward any major reform proposals, assessing the prospects of such reforms to be poor. He managed to end the war with the Ottoman Empire, but the king's subsequent moves met with strong domestic opposition encouraged by Vienna and Berlin. The failure of the Baltic politics led John III to return to the idea of a war with the Porte. Before that, the king had to resolve acute internal conflicts, doing so during the Diet of Grodno in 1679. Only then could he undertake preparations for a new political course. However, the most important factor in the success of the new policy was the opportune development of the international situation at the time.

Keywords: coronation, the Turkish war, Baltic politics, internal conflicts, the Diet of Grodno.

Słowa kluczowe: koronacja, wojna turecka, polityka bałtycka, konflikty wewnętrzne, sejm grodzieński.

Historycy dobrze oceniają politykę Sobieskiego przed rokiem 1683, widząc w niej zwłaszcza duży rozmach i wielkie plany mogące przywrócić świetność Rzeczypospolitej oraz dążenie do wykorzystania pomyślnej koniunktury. W sprawach wewnętrznych miała ona zahamować kryzys państwa. Charakteryzowała się aktywnością w różnych sferach, na przykład wzmocnienia władzy, poprawy parlamentaryzmu lub reform wojskowych. Całościowo jednak ocena polityki wewnętrznej króla nie jest pozytywna, mimo że „Sobieski miał w prawie każdym okresie wśród 
historyków swoich zapalonych miłośników"1. Najważniejszy z nich, Zbigniew Wójcik, stwierdził, że w doprowadzeniu do trwałych zmian przeszkodził niepomyślny dla króla rozwój sytuacji, ,a zresztą przeszkód, które wyrosły przed nim, nie pokonałby chyba nikt...”’. Badacze wskazywali też jako inne przyczyny błędy króla - według nich „był niefortunnym taktykiem”. Czasem wskazuje się, że król bardziej koncentrował się na polityce dynastycznej, a nie na dobru Rzeczypospolitej. Spośród krytycznych opinii możemy przytoczyć osąd Mariusza Markiewicza ${ }^{3}$, który zwrócił uwagę, że Jan III wykazywał niezdecydowanie w polityce wewnętrznej. Z kolei Stanisław Grzybowski podkreślił, że w ocenie Sobieskiego nie odróżnia się propagandy króla i wykreowanego mitu od realiów ${ }^{4}$. Warto więc prześledzić działania monarchy w kilku przełomowych momentach do roku 1679.

Jan Sobieski w chwili elekcji był politykiem niewątpliwie przygotowanym do objęcia obowiązków królewskich. Wpłynęły na to wychowanie oraz wykształcenie. Powszechnie zwraca się uwagę na kult hetmana Stanisława Żółkiewskiego, który wywarł na młodego Jana ogromny wpływ ${ }^{5}$. Trzeba również podkreślić tradycje rodzinne ze strony ojca, zasłużonego dla Rzeczypospolitej parlamentarzysty i dyplomaty. Wykształcenie Sobieski otrzymał typowe dla dziecka magnackiego w pierwszej połowie XVII wieku. Wzorzec wychowawczy opierał się na tradycjach renesansowych, zaadaptowanych do nowej epoki, czego przejawem były gorliwość religijna czy przygotowanie retoryczne. Szczególnie należy podkreślić dużą i ciągle poszerzaną wiedzę Sobieskiego w zakresie historii i geografii. Pobyt w Krakowie i nauka w Kolegium Nowodworskiego oraz w Akademii narodziły w braciach Janie i Marku refleksję na temat stanu Rzeczypospolitej ${ }^{6}$, rozwijaną później podczas kolejnego etapu nauki, jakim była podróż po Europie Zachodniej, odbyta w latach 1646-1648. Konsekwencją takiego wychowania i wykształcenia były szerokie horyzonty umysłowe przyszłego władcy.

Bracia powrócili do ojczyzny późnym latem 1648 roku. Samodzielną działalność polityczną w Rzeczypospolitej zaczęli w okresie kryzysu państwa. Prawdziwym uniwersytetem w nauce życia politycznego Jana Sobieskiego była szkoła królowej Ludwiki Marii. Historycy przyznają, że jedynie osobisty motyw (tzn. związek z Marią Kazimierą) skłaniał Sobieskiego do popierania coraz bardziej zdecydowanych (by nie rzec - awanturniczych) działań pary królewskiej’. Magnat jednak zauważał przy-

1 Recenzja Krystyna Matwijowskiego książki Z. Wójcika o Sobieskim, „Śląski Kwartalnik Historyczny Sobótka" [dalej: Sobótka] 1984, R. IXL, z. 1, s. 101-105.

2 Z. Wójcik, Jan Sobieski 1629-1696, Warszawa 1983, s. 524.

3 M. Markiewicz, Historia Polski 1492-1795, Kraków 2004, s. 588.

${ }^{4}$ S. Grzybowski, Mit Sobieskiego [w:] Odsiecz Wiednia. Prace poświęcone trzechsetnej rocznicy zwycięstwa, Acta Universitatis Lodziensis. Folia Historica, 26, Łódź 1986, s. 115-124.

5 Opinie te zebrał i ocenił Z. Wójcik, Jan Sobieski 1629-1696, rozdział II.

6 Ibidem. Autor przypomniał krytyczne wypracowanie młodego Jana na temat niedostatków sejmu. Wymienić trzeba w tym miejscu pracę Henryka Barycza, która ukazała się później w rozbudowanej wersji: H. Baryc z, Rzecz o studiach w Krakowie dwóch generacji Sobieskich, Kraków 1984.

Podsumowaniem niech będzie inna opinia K. Matwijowskiego z tejże recenzji: „[Sobieski] wychowany na wspaniałych wzorach gotów jest o wszystkim zapomnieć, byle się połączyć z ukochaną kobietą", Matwijowski, op. cit. 
czyny załamania Rzeczypospolitej, które z biegiem czasu przekształciły się w kryzys. Nieufność Sobieskiego do poczynań Jana Kazimierza wynikała z rozumienia mentalności szlachty. Dostrzegał on, że obywatele są przywiązani do swobód szlacheckich, takich jak wolna elekcja czy głos wolny, i nie widzą w nich czynników wpływających na słabość państwa. To nie pozwalało mu działać równie aktywnie na rzecz elekcji vivente rege kandydata francuskiego, jak czynili to inni stronnicy dworu.

W 1667 roku wykpiwany i atakowany przez szlachtę Sobieski odniósł zwycięstwo podhajeckie, co zmieniło nastroje obywateli. Przekonał się wówczas, że w chwili wielkiego triumfu szlachta zapomina o wcześniejszych przewinieniach. Ponadto po wyborze Michała Wiśniowieckiego na króla w 1669 roku zdał sobie sprawę, że królem może zostać człowiek, który nie odznacza się żadnymi pozytywnymi cechami i nie zasłużył się dotychczas dla Rzeczypospolitej. Szlachta broniła tego kandydata w imię zachowania źrenicy wolności, to jest wolnej elekcji. Kolejnym doświadczeniem, które ukształtowało Sobieskiego jako polityka, było odkrycie metody zastraszania przeciwników monarchy groźbą zwołania sejmu konnego. W obliczu poczucia zagrożenia ze strony opozycji (powiązanej z obcym dworem) szlachta zjechała na pospolite ruszenie, aby bronić władcy. Wydarzenia te, które miały miejsce w 1670 roku, a następnie podczas konfederacji gołąbskiej, pokazały siłę szlachty, ale i możliwości sterowania masami. Znane są słowa „populus rozpasany”, których hetman użył w odniesieniu do panów braci ${ }^{8}$. Padły one w chwili wyjątkowego napięcia w Rzeczypospolitej oraz wzburzenia Sobieskiego, spowodowanego konkretnymi wydarzeniami. Kolejne lata pokazały, że potrafił on porozumieć się ze szlachtą9.

Dnia 21 maja 1674 roku Jan Sobieski został wybrany królem polskim. Elekcja nie była jednak jednomyślna: nie zgadzali się na nią Litwini, związani z rodziną Paców. Czynnikiem, który przesądził o wyborze, był entuzjazm szlachty po zwycięstwie chocimskim. Radość z triumfu oraz świadomość zażegnania niebezpieczeństwa osmańskiego spowodowały, że jego autora uznano za najlepszego kandydata do korony. Były również inne czynniki: szlachta wierzyła w ideę króla rodaka (Piasta) i nie zniechęciło jej do niej nieudane panowanie Michała Korybuta. Nie należy lekceważyć też działań żony Sobieskiego, Marii Kazimiery, i wsparcia finansowego Ludwika XIV. Ważną rolę, szczególnie w decydujących chwilach, odegrało poparcie magnackich stronników i rozmaite działania wojskowych ${ }^{10}$. Tym razem Jan Sobieski, mimo widocznej nieufności obywateli wobec Francji i jej stronników, zdecydował się starać o koronę i podjął rozważne działania, które umożliwiły mu to zwycięstwo.

Tuż po elekcji zwolennicy nowego króla musieli przekonać litewskich oponentów. Ostatni etap sejmu elekcyjnego minął pod znakiem wystąpień przeciwników ${ }^{11}$.

8 Z. Wójcik, Jan Sobieski 1629-1696, s. 189.

9 Na powrót do idei współpracy monarchy ze szlachtą zwrócił uwagę Wojciech Szczygielski, W kręgu idei narodowego monarchy [w:] Odsiecz Wiednia..., s. 17-42.

10 Podsumował te opinie Z. Hundert, Wojsko koronne a elekcja 1674 roku [w:] Wokót wolnych elekcji w państwie polsko-litewskim XVI-XVIII wieku, red. zbior., Katowice 2016, s. 308-332.

11 Więcej miejsca poświęcił mu Janusz Woliński, Epilog elekcji 1674 r., „Rozprawy Wydziału Historyczno-Filozoficznego PAU” 1952, seria II, t. XLVI (nadbitka). 
W niektórych sprawach byli oni popierani przez radykalnych wyznawców złotej wolności. Znaczna część posłów koronnych nie uznawała jednak protestacji Żmudzinów, którym zarzucano, że zostali przekupieni ${ }^{12}$. Groźby nie były jeszcze powszechne, nie padło na razie hasło sejmu konnego, ale po wydarzeniach pod Gołębiem protestujący musieli się ich obawiać. Mniejszości blokującej elekcję i zapowiadającej zerwanie sejmu grożono fizyczną rozprawą, argumentując, że nie kieruje się ona dobrem publicznym. Obrady toczyły się na zamku, ale można było przenieść je na pole, gdzie w dalszym ciągu przebywały rzesze popierającej Sobieskiego szlachty. Elekt wykorzystał też do pozyskania niezdecydowanych francuskie pieniądze i wpływy wśród wojskowych. Jednocześnie starał się uspokoić przeciwników, demonstrując wolę współpracy z nimi oraz ich mocodawcami zza granicy - zwłaszcza z cesarzem. Równocześnie widoczne były pojednawcze gesty ambasadora cesarskiego hrabiego Schaffgotscha, który odbył audiencję u elekta, obu stronom zależało bowiem na porozumieniu ${ }^{13}$.

Konfrontacja została więc wygrana przez Sobieskiego, a ważną rolę w odniesieniu tego sukcesu odegrało wykorzystanie doświadczeń z poprzedniej elekcji i panowania Wiśniowieckiego. Podobnie jak w 1669 roku szlachta broniła swojego króla przed intrygami magnatów, ale tym razem to Sobieski został monarchą. Oczywiście nie zlikwidowano wszystkich różnic; napięcia i konflikty możnowładców wciąż istniały, ale te wydarzenia uzmysłowiły monarsze możliwość przyszłych sukcesów we współdziałaniu ze szlachtą.

Sporo czasu poświęcono wówczas kwestii, kiedy powinna odbyć się koronacja. Sobieski dążył do jej odłożenia, argumentując, że Rzeczypospolita ciągle jest zagrożona ze strony Porty i powinna kontynuować wojnę. Przesądziło to o zgodzie szlachty na przesunięcie terminu koronacji. O dacie miał zadecydować elekt, konsultując się z senatorami. Jak się wydaje, najważniejszym powodem, dla którego monarcha postulował przełożenie koronacji, było jego oczekiwanie na kolejne sukcesy. Sobieski pamiętał o ogromnej popularności, jaką przyniosły mu zwycięstwa pod Podhajcami i Chocimiem. Liczył na pomyślne zakończenie wojny (być może kolejnym zwycięstwem), które umocni jego popularność wśród szlachty.

Odłożenie koronacji dawało królowi jeszcze jedną korzyść. Sobieski piastował przed elekcją urzędy hetmana wielkiego i marszałka wielkiego koronnego. Do czasu sejmu koronacyjnego pozostawały one w jego ręku. Mógł więc szachować potencjalnych kandydatów i wymuszać na nich posłuszeństwo. Ponadto wciąż posiadał władzę marszałka i hetmana ${ }^{14}$. Nie należy jednak tego przeceniać. Pole manewru

12 Diariusze z Biblioteki PAN w Kórniku, rkps 385, k. 164; Biblioteki Czartoryskich w Krakowie [dalej: B. Czart] Teka Naruszewicza [dalej: TN] 172, s. 179, 181 oraz diariusz sejmu elekcyjnego [w:] Pisma do wieku i spraw Jana Sobieskiego, wyd. F. Kluczy cki, Kraków 1884, s. 1448 [dalej: Kluczycki].

13 J. Woliński, Poselstwo Krzysztofa Schaffgotscha na elekcję polska 1674 r. [w:] idem, Z dziejów wojny i polityki w dobie Jana Sobieskiego, Warszawa 1960, s. 100-124. Jeden z autorów zapisał już 1 VI, że cesarz kazał swojemu ambasadorowi powinszować objęcia tronu nowemu królowi Polski, s. 179. O tym w diariuszach z B. Czart, TN 172, s. 179, 183 i wydawnictwie Kluczyckiego, s. 1449.

14 Problem ten ocenił K. Matwijowski, Próba reformy urzędu hetmańskiego w czasach Jana III Sobieskiego [w:] Odsiecz Wiednia..., s. 43-52. 
władcy nie było w tej materii zbyt duże - tradycja oraz układ sił faktycznie zmuszały monarchę do powierzenia tych urzędów najpoważniejszym pretendentom. Jak pokazały wydarzenia sejmu koronacyjnego, wakujące godności otrzymali spodziewani kandydaci. Jan III nie podjął decyzji o reformie urzędu hetmańskiego, bo to oznaczałoby konflikt z Dymitrem Wisniowieckim i liczącym na buławę Stanisławem Jabłonowskim, stronnikiem króla. Warto zwrócić uwagę na inny problem: Jan Sobieski w czasie prowadzonej wojny szukał możliwości zwiększenia potencjału państwa. Trudno nie zauważyć, że inne działania (a takim byłoby zmniejszenie kompetencji urzędu hetmana lub obsadzenie stanowiska innym kandydatem niż jeden $\mathrm{z}$,faworytów”) doprowadziłyby do jego osłabienia, a to nie leżało w interesie Sobieskiego. Przesunięcie terminu koronacji było więc konsekwencją toczącej się wojny z Imperium Osmańskim, ale też planów monarchy. Król chciał prowadzić aktywną politykę i wykorzystać dobrą koniunkturę międzynarodową, aby potem przeprowadzić zmiany w Rzeczypospolitej.

Zbigniew Wójcik ocenił, że podczas rady wojennej, która odbyła się w dniach 6-9 czerwca 1674 roku nowy król wygłosił ważne, patriotyczne przemówienie ${ }^{15}$. Jak podsumował, deklaracje polityków często są jedynie czynione na użytek społeczeństwa, ale w tym przypadku nie można ich zignorować. Badacz uznał, że Sobieski kierował się w swojej polityce imponderabiliami. Nie sposób zakwestionować, że działania Sobieskiego były zgodne z racją stanu Rzeczypospolitej.

W dniu 14 czerwca Jan Sobieski wydał uniwersał do szlachty, w którym informował o konieczności obrony ojczyzny „od zbliżających się wielką potęgą nieprzyjaciół Krzyża św.”. Z tego powodu sejm koronacyjny, wyznaczony na dzień 22 lipca, został odłożony do 1 stycznia 1675 roku $^{16}$. W kolejnym uniwersale, wydanym 4 lipca, król przypomniał o odłożeniu aktu koronacji i wydał jednocześnie pierwsze oraz drugie wici $^{17}$. Pospolite ruszenie zostało zwołane 27 lipca. W uniwersałach poruszono problem wydania zaległych podatków i obmyślenia rekompensaty dla wojska. Kwestia ta zasługuje na kilka uwag. Powszechna jest opinia, że Sobieski miał duży uraz do pospolitego ruszenia, spowodowany wydarzeniami pod Gołębiem. Przede wszystkim jednak nisko oceniał jego militarne znaczenie, zebranie się szlachty miało służyć głównie ochronie własnej ziemi. Nie było ono zdolne odwrócić losów wojny, a zbierało się bardzo powoli. Sejmiki odbyły się w połowie sierpnia, przeważnie limitując obrady, ale 20 sierpnia król odwołał trzecie wici. W niektórych źródłach znajdujemy informacje, że król odwlekał zwołanie pospolitego ruszenia, ponieważ nie ufał

15 Z. Wójcik, Jan Sobieski 1629-1696, s. 227-229. O znaczeniu tej rady w czasie toczącej się wojny zob. M. Wagner, Wojna polsko-turecka w latach 1672-1676, t. II, Zabrze 2009, s. 227-229. Autor diariusza zanotował wystąpienie króla: „Dla czego nie chce się kwapić na Koronatią do Krakowa, aż po skończeniu pory woienney, żeby laureatum victoriis caput niosł do niey”, Kluczycki, s. 1450.

16 Uniwersał królewski do województw, Warszawa 14 VI 1674 [w:] J. Woliński, Materiały do dziejów wojny polsko-tureckiej 1672-1676, „Studia i Materiały do Historii Wojskowości” [dalej: SMHW], t. XII, cz. II, s. 275-276.

17 Uniwersał królewski, Warszawa 4 VII 1674 [w:] J. Woliński, Materiały..., SMHW, t. XII, cz. II, s. $279-280$. 
szlachcie, wśród której było sporo malkontentów ${ }^{18}$. Wskazują one na powstawanie nastrojów antykrólewskich, zwłaszcza w Wielkopolsce.

Konsekwencją elekcji Jana Sobieskiego był konflikt Francji z Brandenburgią, której elektor Fryderyk Wilhelm poczuł się oszukany przez Króla Słońce i przyłączył się do koalicji antyfrancuskiej. Wybór ten stanowił jednocześnie sukces sekretnej polityki. Było więc naturalne, że nowy król i Ludwik XIV będą kontynuowali tę politykę i szukali porozumienia. Dotychczasowa kariera polityczna Sobieskiego, która wiązała go ze stronnictwem profrancuskim, oraz wspólne interesy geopolityczne z Ludwikiem XIV kazały mu wybrać drogę porozumienia z Francją. Kolejne działania elektora wzmacniały nieufność i niechęć Sobieskiego do Brandenburgii i doprowadzily do zawarcia traktatu z Ludwikiem XIV w Jaworowie w 1675 roku $^{19}$. Zbigniew Wójcik określił te zamysły jako „wielkie plany królewskie” autorstwa polityka wielkiego formatu ${ }^{20}$. Możliwość uzyskania Prus Książęcych i ograniczenia pozycji Brandenburgii, niedopuszczenie do dominacji Habsburgów w Europie Środkowej, ale też zapobieżenie ekspansji Rosji dawały ogromne możliwości Sobieskiemu i Rzeczypospolitej. Snując wspaniałe wizje, nie należy jednak zapominać o konkretnych celach, które wyznaczał Sobieski. Ich realizacja w teorii wydawała się możliwa. Niewątpliwie najbardziej realnym z nich było umocnienie swych wpływów (i Rzeczypospolitej) nad Bałtykiem. Doprowadziłoby to do znacznego osłabienia Brandenburgii. Nie ma natomiast przesłanek, że nowy król planował wówczas bezpośrednie działania przeciw Habsburgom ${ }^{21}$. Oznaczałyby one otwarcie kolejnego konfliktu, co świadczyłoby o nierealnej ocenie sytuacji geopolitycznej. W czasie trwającej wojny z Imperium Osmańskim należało ponadto dążyć do sojuszu z Moskwą.

Powszechnie uważa się, że ukształtowała się wówczas w Europie koniunktura bardzo korzystna dla państwa polsko-litewskiego. Do podjęcia nowych działań potrzebne było jedynie i aż zakończenie wojny z Portą, co stało się najważniejszym celem króla. Służyły temu przede wszystkim bardzo szeroko zakrojone działania na arenie międzynarodowej ${ }^{22}$. Jednocześnie monarcha dążył do umocnienia swojej pozycji w społeczeństwie. Wykorzystywał do tego propagandę, ponieważ w ustroju demokratycznym do swych racji trzeba wyborców przekonać. Ze względu na sukcesy wojskowe nowy król cieszył się uznaniem i posiadał autorytet. Historycy zgodnie

18 Ibidem, s. 281. Autor pisał jednak, że szlachta ruska stanowi oparcie władcy, ale w wyrażanych przez nią poglądach na sejmikach nie ma odniesień do konfliktów wewnętrznych. J. Stolicki, Wobec wolności i króla. Działalność polityczna szlachty ruskiej, ukrainnej i wołyńskiej w latach 1673-1683, Kraków 2007, s. 86-93.

19 J. Woliński, Sprawa pruska 1673-1675 i traktat jaworowski [w:] idem, Z dziejów wojny i polityki..., s. 16-56.

20 Z. Wójcik, Jan Sobieski 1629-1696, s. 238-241.

${ }_{21}$ Oceny takiej dokonał już Kazimierz Konarski, Polska przed odsieczq wiedeńska r. 1683, Warszawa 1914, s. 9.

22 Literatura na ten temat jest bardzo bogata. Kwestie te podsumowałem w niedawno opublikowanym artykule: J. Stolicki, Działania Jana III w celu wzrostu znaczenia Rzeczypospolitej w Europie w latach 1674-1683, „Studia Środkowoeuropejskie i Bałkanistyczne” 2017, t. XXV, red. I. Stawowy-Kawka, s. $27-41$. 
zwracają uwagę na nastroje entuzjazmu panujące wśród szlachty po elekcji ${ }^{23}$. W atmosferze zadowolenia z jej wyniku z osobą Jana Sobieskiego wiązano nadzieje na pozytywne zmiany w państwie. Pojawiały się opinie, że nowy król odrodzi świetność Rzeczypospolitej po wcześniejszych niepowodzeniach, a ich konsekwencją były też marzenia lub wizje absolutystycznego zamachu stanu, na które wskazał Krystyn Matwijowski ${ }^{24}$. Myślano o reformach, które miały ograniczyć wpływy przeciwników dworu, zwłaszcza na Litwie. Obóz dworski dążył jednak do wprowadzenia takich zmian, które spotkają się z aprobatą szlachty. W trakcie prowadzonej wojny trzeba było łagodzić spory wewnętrzne, żeby nie osłabiać państwa, i tak postępował Sobieski.

Nie zamilkli jednak jego przeciwnicy, którzy po elekcji groźbami zostali zmuszeni do rezygnacji ze sprzeciwu wobec jej wyniku. Wprawdzie w jednej relacji zapisano, że byli oni znani królowi, który mógł ich uważnie obserwować i neutralizować te działania, ale sprawiało mu to wyraźne trudności. Szczególnie niechętna była mu większość elit litewskich. O tym oczywiście powszechnie wiedziano, ale w związku z tym król nie mógł liczyć na wsparcie wojska litewskiego, w którym dominowali zwolennicy Paców, uważający, że podczas elekcji złamano prawo ${ }^{25}$. Wskazywano też na kroki opozycji mające na celu osłabienie pozycji monarchy poprzez podsycanie obaw szlachty, że nowy władca ograniczy jej wolności. I wreszcie trzeba przypomnieć opinie, że król, obawiając się ataków przeciwników, nie chciał zwoływać pospolitego ruszenia. Najgorsze skutki przyniosła jednak pasywność szlachty, która pozostała głucha na wezwania monarchy wypłaty funduszów na wojsko.

W sierpniu 1674 roku Sobieski na czele armii udał się na Ukrainę, licząc na zakończenie wojny. W uniwersale wydanym 23 października zapowiedział odłożenie koronacji, co argumentował działaniami wojennymi ${ }^{26}$. Apelował również o realizację postanowień podatkowych i wysłanie piechot łanowych. Przesunięcie koronacji nie przyniosło jednak oczekiwanych korzyści. Słabość wewnętrzna państwa uwidaczniająca się szczególnie w niewydolności aparatu fiskalnego i trudnej sytuacji ekonomicznej wpłynęła na rezultaty działań wojennych. Zabrakło wielkiego zwycięstwa, na miarę oczekiwań nowego króla. Udało się uzyskać jedynie przewagę taktyczną na Ukrainie. Sukcesy oręża wzmacniały jednak pozycję monarchy wśród szlachty. Jego aktywność usprawiedliwiała kolejne decyzje o odroczeniu koronacji. Lato 1675 roku minęło pod znakiem kolejnych ważnych rokowań dyplomatycznych. Wznowienie działań wojennych nastąpiło w czerwcu. Przyniosły one spektakularne zwycięstwo nad Tatarami koło Lwowa oraz sukces obrony manewrowej ${ }^{27}$. Towarzyszyło

23 Z. Wójcik, Jan Sobieski 1629-1696, s. 220-221; K. Matwijowski, Czy Sobieski zamierzal dokonać absolutystycznego zamachu stanu [w:] Studia z dziejów epoki Jana III Sobieskiego, red. K. Matwijowski, Wrocław 1984, s. 75-87.

24 Autor przeanalizował sytuację i rozszerzył swoje wcześniejsze badania, ibidem, passim.

25 J. Woliński, Materiaty..., SMHW, t. XII, cz. II, s. 281, 283-284, 286-287. O pismach antykrólewskich pisał Z. Wójcik, Jan Sobieski 1629-1696, s. 221-226.

${ }^{26}$ Uniwersał królewski. W zamku złoczowskim, 23 X 1674 [w:] J. Woliński, Materiały..., SMHW, t. XII, cz. II, s. 311-312.

27 Kampanię podsumował M. Wagner, op. cit., rozdz. VIII. 
im jednak wyraźne umocnienie się Rosjan na Ukrainie. Po zakończeniu kampanii 7 listopada $1675 \mathrm{roku}$, podczas rady senatu w Czarnokozincach podjęto decyzję o zwołaniu sejmu koronacyjnego.

Podjęte przez Jana Sobieskiego po elekcji kroki mające na celu zakończenie wojny z Imperium Osmańskim nie przyniosły powodzenia. W kwestiach wewnętrznych starał się o utrzymanie życzliwości szlachty (także poprzez zwalczanie niechętnej propagandy) oraz dobre przygotowanie państwa do wojny, którego głównym elementem było wzmocnienie wojska. Tego ostatniego nie udało się jednak osiągnąć.

$\mathrm{Na}$ sejmie koronacyjnym, rozpoczętym 4 lutego 1676 roku, zwiększono liczbę wojska oraz uchwalono wysokie podatki, co było podstawowym celem monarchy ${ }^{28}$. Postulował on jak najlepsze przygotowanie armii do decydującej kampanii. Pamiętał jednak, że szlachta w ostatnich dwóch latach nie wywiązała się z wcześniejszych zobowiązań finansowych. Skupił się więc na tworzeniu i uzupełnieniu tych jednostek wojska, które wymagały jak najmniejszych nakładów finansowych. Nie podjął ponadto żadnego innego planu reform, aby skoncentrować się na najważniejszym celu i nie dawać przeciwnikom argumentów. Buławy zostały rozdane dziesięć dni później niż inne wakanse. Można ocenić, że monarcha sondował nastroje szlachty w sprawie osłabienia kompetencji urzędu hetmańskiego ${ }^{29}$.

Postanowienia sejmu koronacyjnego dotyczące kwestii podatkowych nie zostały jednak zrealizowane podczas sejmików posejmowych. W większości limitowały obrady, nie podejmując oczekiwanych uchwał względem wybierania podatków i odraczając powołanie wypraw wojewódzkich ${ }^{30}$. Niechętną monarsze działalność prowadzono w Wielkopolsce ${ }^{31}$. Tamtejsza szlachta kilkakrotnie limitowała obrady, a za czwartym razem, 12 sierpnia, sejmik został zerwany. Podjęte zobowiązania były bardzo skromne, każdorazowo obywatele podkreślali, że wywiązują się ze swych powinności i narzekali na zniszczenia będące skutkiem przechodów wojska. Wielkopolanie skarżyli się, że nie zostały potwierdzone pakta z sąsiadami, a relacje brandenburskie wskazują na duży posłuch antykrólewskich działań elektora. Postawa szlachty wpłynęła na stan armii, której nie udało się znacząco powiększyć. Kampania roku 1676 zakończyła się obroną obozu w Żórawnie przed dużą armią nieprzyjaciela ${ }^{32}$. To okazało się kolejnym doświadczeniem dla Sobieskiego, który zrozumiał, że prowadzenie wojny z tak potężnym nieprzyjacielem jedynie własnymi siłami jest bardzo trudne. Postanowienia rozejmu (bardzo ogólnikowe) miały zostać potwierdzone przez wielkiego posła.

28 Sejm został omówiony przez K. Matwijowskiego, Pierwsze sejmy z czasów Jana III Sobieskiego, Wrocław 1976, s. 91-140.

29 Idem, Pierwsze sejmy..., s. 123-132.

30 Obszernie omówił tę kwestię K. Matwijowski, ibidem, s. 142-149. Autor ocenił, że do faktycznego sparaliżowania państwa przyczyniła się działalność opozycji.

31 Akta sejmikowe województw poznańskiego i kaliskiego. Lata 1675-1695, wyd. M. Zwierzykowski, R. Kołodziej, A. Kamieński [dalej: ASWPiK], s. 5-39. Podczas sejmu kwestia potwierdzenia paktów z innymi państwami pojawiła się jedynie pod koniec obrad i nie wywołała większych dyskusji. Przywołanie jej więc po sejmie należy ocenić jako pretekst do wystąpień przeciw królowi, inspirowanych z zewnątrz. Diariusz sejmu w B. Czart, rkps 423, s. 489.

32 O kampanii zob. M. Wagner, op. cit., rozdz. IX. 
Po Żórawnie król zwołał sejm na 14 stycznia 1677 roku. Jego głównym zadaniem było podjęcie decyzji w sprawie pokoju z Portą i wysłania poselstwa do Stambułu oraz prowadzenia rokowań z Moskwą ${ }^{33}$. Do tego też Sobieski próbował skłonić szlachtę. Obrady przebiegały pod znakiem wielu konfliktów. Opozycja, inspirowana przez dwory w Berlinie i Wiedniu, niekiedy kierując się podszeptami ze strony Watykanu, działała przeciw zamysłom króla. Dążył on więc, aby wszelkie przeszkody, które mogły temu zapobiec, zostały usunięte. Liczył jednak, że podpisany pokój zostanie oparty na zasadzie terytorialnego status quo. Oznaczało to, że w rękach tureckich pozostanie Kamieniec, ale Korona zachowa większość Podola, z mniejszymi twierdzami, obsadzonymi polskimi załogami. Dobra znajdujące się wokół nich często należały do wpływowych magnatów. Ponieważ szlachta pragnęła pokoju, argumenty króla były znacznie silniejsze niż jego przeciwników, którzy właściwie musieli zgodzić się z propozycjami monarchy. Opozycja przedstawiała wówczas dążenia pokojowe Jana III jako wynikające z zamysłów dyplomacji francuskiej, która dąży do porozumienia z Portą, po to, aby doprowadzić do wojny z państwem carów i przeciwnikami Francji. Nowy konflikt miał służyć interesom Ludwika XIV i pomóc Sobieskiemu we wprowadzeniu absolutyzmu. W celu uspokojenia szlachty i osłabienia propagandy przeciwników król nie oponował zanadto przeciw potwierdzeniu układów z cesarzem i elektorem. A to przecież przeciwko elektorowi miały być skierowane planowane działania, przeciw cesarzowi zaś pewne kroki już zostały podjęte.

W tym czasie zapadło kilka decyzji, które zaowocowały wzrostem napięcia w państwie. Najpoważniejszym błędem, jaki popełniono, była redukcja wojska ${ }^{34}$. Nastąpiło to wbrew królowi i osłabiło pozycję Rzeczypospolitej w czasie przyszłych rokowań z Portą, czego można się było spodziewać. Król zgodził się, aby żołnierze $\mathrm{z}$ rozwiązanych oddziałów przystąpili do zaciągów węgierskich, wysyłanych na odsiecz powstańcom antyhabsburskim, a częściowo wziął ich na swój, to jest francuski, żołd. Organizatorem tych działań był bardzo popularny w wojsku kawaler maltański Hieronim Lubomirski, pozyskany przez dyplomatów francuskich ${ }^{35}$. Akcja ta spotkała się ze zdecydowanym przeciwdziałaniem stronników habsburskich i skonsolidowała opozycję, mimo że Sobieski oficjalnie odcinał się od tych działań. Spowodowała, że Lubomirski osobiście nie wyruszył na Węgry. Stanowiła cenę za wsparcie finansowe otrzymywane od Ludwika XIV. Sprawa redukcji wojska miała też inne negatywne konsekwencje: nie doszło do zwinięcia armii litewskiej, co dawało hetmanowi Michałowi K. Pacowi duże możliwości w przyszłych działaniach przeciw królowi.

Kłopotów przysparzała monarsze działalność komisji wojskowych, które miały doprowadzić do wypłaty żołdu dla wojska. Opozycja nie dopuściła do rozpoczęcia prac w przeddzień sejmu w Warszawie, więc odłożono ją do czasu sejmu

33 Przedstawił tę politykę Z. Wójcik, Rzeczpospolita wobec Turcji i Rosji 1674-1679, Wrocław 1976, s. 88-105.

34 O tych problemach pisali i dokonali ich podsumowań K. Matwijowski, Pierwsze sejmy..., s. 195, 210-229, 232, oraz Z. Wój cik, Jan Sobieski 1629-1696, s. 264-268.

35 Kwestie te przedstawił K. Piwarski, Hieronim Lubomirski hetman wielki koronny, Kraków 1929, rozdz. II. 
w Sandomierzu, a litewska komisja odbywała się w Wilnie. Prace postępowały powoli z powodu braku pieniędzy na opłacenie wojska, a negatywne nastroje uderzały $\mathrm{w}$ monarchę.

Błędem Sobieskiego było zrażenie do siebie duchowieństwa. Rada senatu postanowiła, że wojsko będzie stacjonowało w dobrach duchownych. Król starający się o podtrzymanie życzliwości szlachty nie chciał jej obciążać kosztami utrzymania armii. Decyzja ta wzbudziła jednak niechęć biskupów. Ważną rolę wśród nich odegrał biskup krakowski Andrzej Trzebicki, zadeklarowany stronnik Habsburgów. W przeciwieństwie do prymasa Andrzeja Olszowskiego, zdecydowanie występował przeciw monarsze i współdziałał z jego przeciwnikami ${ }^{36}$. Potępiał głównie antycesarskie działania na Węgrzech.

Sejm podjął decyzję o wysłaniu poselstwa do Stambułu. Rozwiązało to częściowo ręce królowi, który po zakończeniu obrad udał się do Gdańska, aby być w pobliżu wydarzeń decydujących o losach polityki bałtyckiej, której realizacja zaczęła nastręczać poważnych trudności.

Warto w tym miejscu zauważyć, że wywyższenie Sobieskiego wzbudziło niechęć niektórych magnatów, wcześniej działających w tym samym obozie politycznym. Nie wszystkie decyzje króla dotyczące rozdawania wakansów należy ocenić jako fortunne. Zwróciłem przed laty uwagę, że Jan III nie kierował się podobnymi przesłankami, co Ludwika Maria i Jan Kazimierz ${ }^{37}$. Odrzucał nie tylko metody stosowane przez parę królewską, które budziły niechęć szlachty, ale także koncepcję, że dzięki rozdawaniu urzędów stworzy się silne i sprawne stronnictwo dworskie. Pozyskanie wszystkich i utrzymanie ich w jednym obozie nie były możliwe. A narastanie wewnętrznych konfliktów czy upadek autorytetu monarchy (zwłaszcza Piasta) powodowały, że w latach 70 . stawały się coraz bardziej nierealne. Jan III starał się więc zdobyć poparcie określonych magnatów do konkretnych zadań, przed którymi stanie obóz dworski, i usuwał przeszkody na drodze do ich realizacji. Krytycznie ocenia się nominację Jana Wielopolskiego na urząd podkanclerzego koronnego ${ }^{38}$, co spowodowało odsunięcie się od dworu Krzysztofa Grzymułtowskiego. Trzeba jednak zauważyć, że Wielopolski odgrywał w tym czasie ważną rolę w obozie dworskim. Król zaś musiał zadbać o utrzymanie silnych wpływów w Małopolsce, w sytuacji gdy mocno atakowany był Hieronim Lubomirski, zwłaszcza że przeciwko polityce króla występował cieszący się dużym autorytetem biskup Andrzej Trzebicki, który posiadał spory wpływ na szlachtę mieszkającą na terenach diecezji krakowskiej. Pozytywnie trzeba jednak ocenić nominacje nadane w pierwszym okresie panowania

36 O działaniach Trzebickiego zob. A. Przyboś, M. Rożek, Biskup krakowski Andrzej Trzebicki. Z dziejów kultury politycznej i artystycznej w XVII stuleciu, Warszawa-Kraków 1989, s. 112-118.

37 J. Stolicki, Rozdawnictwo wakansów przez Jana III jako metoda tworzenia partii dworskiej [w:] Faworyci i opozycjoniści. Król a elity polityczne w Rzeczypospolitej XV-XVIII wieku, red. M. Markiewicz, R. Skowron, Kraków 2006, s. 359-375. Wpływ Marii Kazimiery dotychczas nie został zbadany, poza kilkoma spektakularnymi przypadkami. Zasługuje on na osobną analizę, stąd zdając sobie sprawę z jego znaczenia, zostawimy go na boku tych rozważań. Podobnie dla naszych rozważań nie jest najważniejsza kwestia sprzedaży urzędów.

38 Wyraził taką opinię K. Matwijowski, Sejm grodzieński 1678-1679, Wrocław 1985, s. 17-18. 
Sobieskiego. Podczas sejmu koronacyjnego ważne urzędy król przyznał podkomendnym z wojska oraz sprzyjającym mu duchownym ${ }^{39}$.

Podczas pobytu monarchy w Gdańsku nastąpiło znaczne zaostrzenie sytuacji w Rzeczypospolitej. Był to skutek wydarzeń na Węgrzech oraz przygotowań Szwedów do zaatakowania Prus Książęcych. Przeciwnicy dworu, inspirowani przez Berlin i Wiedeń, ostro krytykowali politykę Jana III i jego stronników. Ważną rolę wśród nich odgrywał wspomniany już biskup Trzebicki, który był nieformalnym przywódcą opozycji i inspirował innych do konkretnych działań przeciwko królowi ${ }^{40}$. Popierali go długoletni nieprzyjaciele Sobieskiego, jak Pacowie, ale sytuację wykorzystał dla własnych celów również hetman wielki koronny Dymitr Wiśniowiecki. Od 1673 roku trwał w Rzeczypospolitej spór między nim a Hieronimem Lubomirskim o ordynację ostrogską, której dobra zostały bezprawnie i zbrojnie zajęte przez Wiśniowieckiego.

W pierwszej połowie 1678 roku załamały się „wielkie plany królewskie”. Rokowania prowadzone przez Gnińskiego w Stambule od początku układały się niekorzystnie i mimo wysiłków posła nie zmieniło się wrogie nastawienie dygnitarzy osmańskich, zwłaszcza wezyra. Układ zawarty 13 kwietnia był klęską dyplomatyczną i upokorzeniem Rzeczypospolitej. Na północy działania Szwecji, sojusznika Sobieskiego, okazały się nieudolne i przyniosły jej ciąg porażek. Na domiar złego wojna w Europie Zachodniej zbliżała się do końca, co w ówczesnej sytuacji groziło izolacją polityczną państwa polsko-litewskiego. W tej sytuacji Ludwik XIV zaprzestał popierania i finansowania swoich zwolenników w Rzeczypospolitej ${ }^{41}$. Jan III został zmuszony do reorientacji polityki zagranicznej. Musiał również doprowadzić do pacyfikacji wewnętrznej i ochronić swoich stronników, głównie Lubomirskiego. W tej kwestii mógł liczyć, ostatni już raz, na poparcie ambasadora de Béthunego. Niezadowolenie wobec Francji i jej ambasadora wykazywała Maria Kazimiera. Béthune musiał więc zbudować nowe stronnictwo francuskie, już bez króla. Kampania opozycji skierowana przeciw zwolennikom Francji trwała jednak nadal. Nie zostało udowodnione zawarcie spisku antykrólewskiego, którego celem byłaby detronizacja Jana III i wprowadzenie na tron księcia Karola Lotaryńskiego. Widocznych było jednak wiele działań przeciwników monarchy. Z tych powodów Jan Wielopolski, niewątpliwie z rozkazu króla, zajął z wojskiem Częstochowę i kilka twierdz na pograniczu śląskim, co nasiliło konflikty wewnętrzne.

W napiętej sytuacji wewnętrznej król zwołał sejm w Grodnie ${ }^{42}$. Sobieski zdecydował się na podjęcie nowej polityki i zerwał z Francją. W legacji na sejmiki monarcha skoncentrował się na sprawach międzynarodowych ${ }^{43}$. Wyraźnie akcentował

39 O rozdaniu wakansów 3 III 1676 r. zob. idem, Pierwsze sejmy..., s. 123.

40 Podsumowanie działań biskupa zob. A. Przyboś, M. Rożek, op. cit., s. 115-118 oraz J. Stolicki, Biskupi krakowscy wobec polityki Jana III Sobieskiego [w:] Kościót Katolicki w Małopolsce w średniowieczu i we wczesnym okresie nowożytnym, red. W. Kowalski, J. Muszyńska, Kielce 2001, s. 372-374.

${ }^{41}$ Kwestie te przedstawił K. Konarski, op. cit., Warszawa 1914, rozdz. III.

42 K. Matwijowski, Sejm grodzieński..., rozdz. I.

43 Instrukcja króla Jana III na sejmik przedsejmowy województwa podolskiego we Lwowie 3 XI 1678 r. [w:] Akta sejmiku podolskiego in hostico 1672-1698, wyd. i oprac. J. Stolicki, Kraków 2002, s. 55-62. Omówił ją K. Matwijowski, Sejm grodzieński..., s. 29-32. 
widoczną słabość państwa. Przypomniał kolejne błędy popełniane podczas ostatniej wojny polsko-tureckiej. Ich skutkiem było podpisanie bardzo niekorzystnego pokoju, który trzeba było na sejmie potwierdzić. Krytycznie ocenił działania podjęte podczas poprzedniego sejmu dotyczące poselstwa do Moskwy. Tylko dzięki interwencji samego monarchy przyniosły one pozytywne rozstrzygnięcia. W instrukcji król wskazał też na słabość wewnętrzną, zwłaszcza pustki w skarbie. Jan III przygotowywał wówczas grunt pod nową politykę i pragnął uświadomić szlachcie konieczność zabezbieczenia państwa na wypadek kolejnego zagrożenia ze strony Imperium Osmańskiego. Na razie nie proponował otwarcie wznowienia wojny z Portą, co uzasadniał trudnym położeniem Rzeczypospolitej. Konieczna była zgoda sejmu na warunki pokoju, król przedstawił więc zagrożenie wynikające z sąsiedztwa $\mathrm{z}$ agresywnym sąsiadem oraz względnie korzystne relacje z Moskwą. W ówczesnym położeniu była to jedyna możliwa taktyka działania. Mocno podkreślił, że w tej trudnej sytuacji instytucje Rzeczypospolitej nie zdają egzaminu, i chciał, aby szlachta przyjęła tę krytykę i zgodziła się z pewnymi rozwiązaniami naprawczymi. Obawiał się jednak, aby przeciwnicy nie zarzucali mu, że podważa zasady ustrojowe czy wolności szlacheckie.

Argumenty zawarte w legacji są bardzo podobne do tych, które wykorzystywano w publicystyce dworu z tego okresu. W anonimowym traktacie Rozmowa ziemianina ze statysta ${ }^{44}$ autor przedstawia poglądy monarchy, zgodnie z którymi z powodu zagrożenia osmańskiego trzeba przygotować się do wojny oraz zwiększyć kompetencje króla w zakresie obrony. Na niektóre bolączki państwa mógł wskazać sam Jan III, ale inne lepiej było przedstawić anonimowemu szlachcicowi, zaniepokojonemu groźbą nowej wojny z Portą i słabością Rzeczypospolitej.

Stosunkowo wiele miejsca $\mathrm{w}$ tych dokumentach oraz $\mathrm{w}$ innych pochodzących z pierwszego okresu panowania Sobieskiego zajmuje diagnoza stanu państwa, natomiast brak w nich konkretnych rozwiązań. Monarcha jakby oczekiwał od szlachty, że to od niej wyjdą propozycje takich działań. Propozycji szlachta jednak nie przedstawiła. Król zaś nigdy na sejmie nie domagał się reform, co było konsekwencją tego, że zawsze miał inne priorytety. Obawiał się, że wywołałyby wśród szlachty opór. Pomysły i programy reformatorskie Sobieskiego są dość wysoko oceniane przez historyków, ale właściwie nie zwraca się uwagi, że nie spotkały się one z żadnym odzewem. Dwór zaś ich nie forsował, ponieważ pierwszoplanowe cele były inne. I z tego też Sobieski w późniejszym czasie (po Wiedniu) wyciągnął wnioski, rezygnując z ich przedstawiania opinii szlacheckiej.

Opozycjoniści podjęli zdecydowane działania przeciwko zwolennikom monarchy, a szczególnie ostry atak był skierowany na Hieronima Lubomirskiego i podkanclerzego Jana Wielopolskiego. Hetman wielki koronny Dymitr Wiśniowiecki wysłał dwa listy na sejmiki. W drugim, obszerniejszym, żądał wydania na Lubomirskiego mandatu ${ }^{45}$. Prosił kanclerza Krzysztofa Paca o wsparcie dla jego postulatów zgło-

44 Rozmowa czyli dyjalog ziemianina z statysta o pokoju z Turczynem zawartym i o przyszlych majacych nastapić rzeczach, B. Czart TN 176, s. 595-609. Z. Wójcik, Rozmowa ziemianina ze statysta, „Sobótka” 1975, R. XXX, s. 321-333.

45 Listy te zostały wydane w: ASWPiK, s. 151-156. Drugi z nich został dołączony do korespondencji wysłanej elektorowi przez jego rezydenta Wicherta. 
szonych sejmikom litewskim ${ }^{46}$. Hetman wykorzystał zaangażowanie Lubomirskiego na Węgrzech i jego pomoc dla powstańców. Przedstawił go jako prowodyra rewolty i zarzucił mu udział w zabójstwie podkomorzego łęczyckiego Stefana Sarnowskiego.

Wcześniej Lubomirski pisał w liście do Krzysztofa Paca: „uwzięte odium przeciwko mnie ks. jmp. w-dy bełskiego z okazyi ordynacyi ostrogskiej”. W związku z tym „ogłosił mnie woj. bełski zaciągów węgierskich complicem nie mając żadnego fundamentu, tylko z przyjaźni mojej z jmp. markizem... przydał mi też calumniosam zabójstwo podkomorzego łęczyckiego i listy po województwach powysyłano kłamliwe" ${ }^{47}$. Wysłał również dwa listy do zgromadzeń szlacheckich.

Informator Michała Paca Jarosz Wawrzecki zawiadamiał swojego mocodawcę o staraniach Lubomirskiego mających na celu doprowadzenie do wydania mandatów na hetmana, który mimo przestróg króla nie podjął działań przeciw oddziałom wojskowym udającym się na Węgry ${ }^{48}$. Podobne argumenty znalazły się w liście króla do wojewody ruskiego Stanisława Jabłonowskiego. Monarcha podkreślał, że nie wiedział nic o zaciągach, a Wiśniowiecki, dopuszczając do nich, zaniedbał swoje obowiązki. Jak sugerował monarcha, książę Dymitr, wysyłając ponadto listy na sejmiki, w których atakował Wielopolskiego, przyczynił się do narastania dyfidencji i zaostrzenia konfliktów oraz zrywania zgromadzeń ${ }^{49}$.

Z licznych listów biskupa Trzebickiego warto zwrócić uwagę na pewien fragment: „Nie wiem co to jest, że p. podkanclerzy nowy pyta niektórych swoich przyjaciół coraz: a wm. mp na sejmie, na sejmiku bedziesz stał przy królu Jm. czy przeciwko niemu? Wszyscy przy Królu JM. stajemy i stać powinniśmy, bośmy mu przysięgli salvis legibus nostris stać będziemy przy nim. A na cóż te examina, na co te fakcyje scissiones, septi rationes czyni ten nowy minister?" ${ }^{50}$. Przebija z niego nie tylko niechęć do przeciwnika, ale i obawy przed skutecznością działań podjętych przez dwór.

Sejmiki wypadły nie najgorzej dla dworu. Krystyn Matwijowski ocenił, że argumenty monarchy w sprawie relacji z Portą i Moskwą zostały przez szlachtę uwzględnione $^{51}$. Generalnie szlachta nie wypowiadała się na temat traktatu podpisanego przez Gnińskiego, przyjmując (niechętnie i wstydliwie) jego postanowienia. Z nielicznych i pośrednich wzmianek dotyczących tej kwestii jednoznacznie jednak wynika, że nie chciała zrywać pokoju. Takie stanowisko wyrazili także Podolanie, najbardziej zainteresowani zablokowaniem pokoju, co dawało im nadzieję na powrót do swych

46 List Dymitra Wiśniowieckiego do Krzysztofa Paca, Dubno 11 X 1678, Archiwum PAN Warszawa, Materiały Janusza Wolińskiego, teka 66, k. 225-226. K. Piwarski, op. cit., s. 15-17.

47 H. Lubomirski kawaler maltański do K. Paca, 26 VIII 1678, Archiwum PAN Warszawa, Materiały Janusza Wolińskiego, teka 66, k. 211-212. Te listy również znajdują się w ASWPiK.

48 Kopia listu pisanego od jm. pana Wawrzeckiego do jm. pana wojewody wileńskiego, die 16 XI, z Lubomla, B. Czart TN 176, s. 329-331.

49 JKM do jm. pana wojewody ruskiego, w Białej 13 XI 1678, B. Czart TN 176, s. 311-312.

50 Trzebicki do K. Paca, bd. i m. Arch. PAN Warszawa, Materiały Janusza Wolińskiego, teka 66, k. 271-272.

${ }^{51}$ K. Matwijow ski, Sejm grodzieński..., s. 46-66. Autor stawia tezę (s. 65), że dawało to królowi nadzieję na rewizję stosunków z Portą, i z tą opinią należy się zgodzić. J. Stolicki, Wobec wolności i króla..., s. 186-196. 
majętności. Ataki przeciwników Sobieskiego na prowadzoną przez niego politykę zagraniczną, tak liczne w ciągu ostatniego roku, nie wpłynęły na postawy obywateli.

Drugim sukcesem obozu dworskiego były relatywnie niewielkie reperkusje polityki bałtyckiej i zaciągów węgierskich. Kwestie te wzbudziły oczywiście zastrzeżenia części szlachty, ale jeżeli uwzględnimy wcześniejsze wrzenie, to opinie wyrażone w instrukcjach nie były dla dworu bardzo niekorzystne. Na niektórych zgromadzeniach doszło wprawdzie do zatargów, które spowodowały duże zamieszanie i nawet zerwanie sejmików, ponieważ aktywność opozycji wpłynęła na narastanie waśni wewnętrznych. W znanych nam instrukcjach dominuje jednak przeświadczenie szlachty, że monarcha powinien uspokoić wszelkie animozje, także na przykład konflikt o ordynację ostrogską.

W większym stopniu o napięciach świadczą relacje nuncjusza Martelli. Wprawdzie informacje ambasadorów państw obcych powinniśmy interpretować ostrożnie, ale w tych znajdujemy potwierdzenie problemów przedstawianych w korespondencji. Według nuncjusza król deklarował gotowość podjęcia działań antytureckich w przyszłości, ale jako warunek stawiał sojusz z Moskwą. Nieufnie do tych zamierzeń byli jednak nastawieni senatorowie. Opinia Martelli była zgodna z intencjami monarchy. Był on zainteresowany uspokojeniem sytuacji wewnętrznej i dążył do pomyślnego zakończenia sejmu ${ }^{52}$, dlatego też nie zostały wydane mandaty. Dla zdobycia przychylności Wiśniowieckich Dymitr otrzymał województwo krakowskie, a Konstanty po nim bełskie. Konflikt wewnętrzny w Rzeczypospolitej był związany z rywalizacją obcych mocarstw, magnaci byli bowiem ich stronnikami. W związku z tym nuncjusz liczył, że pokój Francji z cesarzem ułatwi pomyślne zakończenie sejmu. Ważną przyczyną tego konfliktu był też spór o ordynację ostrogską. Ciekawe są opinie nuncjusza dotyczące wykorzystywania szlachty przez możnych dla ich interesów.

Sejm grodzieński minął pod znakiem wielu sporów, zarówno związanych z bieżącymi wydarzeniami politycznymi, jak i dotyczących funkcjonowania tej instytucji ${ }^{53}$. Trzeba zgodzić się z opinią Kazimierza Konarskiego, że zakończył się on sukcesem króla, który doprowadził do uspokojenia konfliktów wewnętrznych ${ }^{54}$. Dużego wsparcia udzielał mu nuncjusz, wyraźnie popierający antytureckie zamierzenia monarchy. Naciskał na jego przeciwników, aby nie przedstawiali swoich pretensji dla dobra publicznego ${ }^{55}$. Wpływał ponadto na posła cesarskiego, aby ten nie podnosił zanadto zastrzeżeń w sprawie zaciągów. Do porozumienia między Lubomirskim

52 Biblioteka PAU-PAN Kraków, Teka Rzymska 8431, s. 98-100 (relacje z 5 X, 12 X i 19 X 1678), 108-111 (relacje z 2 XII, 18 XII i 25 XII). Obawy przed zerwaniem sejmu wyrażał nie tylko monarcha, ale nuncjusz nie podaje nazwisk innych osób. Jan III deklarował, że zapomni o intrygach. Wyjaśniał, że wprowadzenie załogi do Częstochowy nie było krokiem antycesarskim, ale wynikało z obaw przed zajęciem jej przez malkontentów (na co były dowody).

53 Te kwestie zostały przedstawione przez Roberta Kołodzieja, ,Ostatni wolności naszej klejnot”. Sejm Rzeczypospolitej za panowania Jana III Sobieskiego, Poznań 2014; K. Matwijowski, Sejm grodzieński..., rozdz. III.

54 K. Konarski, op. cit., s. 54-59.

55 Biblioteka PAU-PAN Kraków, Teka Rzymska 8431, s. 118, 120, 125 (relacje z 1 I, 8 I i 15 I 1679) O działaniach podczas sejmu w celu porozumienia magnatów w diariuszu w B. Czart. TN 176, s. $445-498$. 
i Wiśniowieckim powołano deputację, ale ważną rolę w doprowadzeniu do niego odegrała też królowa Maria Kazimiera. Nie było to łatwe; nie udało się go zrealizować w czasie przerwy świątecznej. Kiedy jednak zawarto je 1 lutego, wszyscy byli zadowoleni ${ }^{56}$. Magnaci wycofali wzajemne oskarżenia, a sprawę ordynacji ostrogskiej odłożono, tym samym zostawiając ordynację w chwilowym posiadaniu księcia Dymitra. Niedawno przedstawiłem następującą ocenę polityki monarchy, którą dziś podtrzymuję: „Król wydostał się z trudnej sytuacji bez ujmy dla autorytetu i szkody dla swych zwolenników, w dodatku zaskoczył przeciwników zmianą koncepcji i narzucił kierunek działań, które niedługo zostaną uwieńczone sukcesem. Wykazał się przenikliwością w diagnozach i skutecznymi receptami z korzyścią dla Rzeczypospolitej"57.

Stany wyraziły zgodę na wysłanie poselstw do państw europejskich w poszukiwaniu sojuszników do przyszłej wojny z Portą. Oznaczało to aprobatę szlachty na proponowaną przez króla reorientację polityki zagranicznej. Sejm zgodził się na powołanie deputatów, którzy powinni doradzać królowi w sprawie pokoju i wojny aż do przyszłego sejmu. Oznaczało to przyznanie monarsze uprawnień w zakresie spraw obronnych, co kręgi dworskie wyraźnie wówczas postulowały ${ }^{58}$. Sejm uznał jednak, że wojny z Portą „,teraz jednak wykonać niepodobna”, więc zalecił działania mające na celu utrzymanie pokoju. Była to polityka przemyślana i prowadzona w sposób rozważny. Król nie kierował się emocjami, nie działał w pośpiechu, lecz starannie przygotowywał szlachtę do zmian w sytuacji międzynarodowej, a nawet starał się kreować te zmiany.

Ważną rolę w kolejnych działaniach dworu odgrywała propaganda, w której dominowały opinie antytureckie. Jej celem było przekonanie szlachty, że pokój ze Stambułem jest chwilowy i należy spodziewać się kolejnej wojny. Częściej pojawiały się argumenty, że Porta uderzy na Kraków od strony Węgier. Na korzyść dworu działała też zaborczość Turków, widoczna podczas rozgraniczenia Podola, pogłębiająca obawy przed zagrożeniem osmańskim. Celem propagandy było utrzymanie nastrojów antytureckich, ale rzeczywiste działania zostały skoncentrowane na polityce europejskiej. Wojna miała być prowadzona przez koalicję państw europejskich ${ }^{59}$. Po zakończeniu sejmu sytuacja nie układała się początkowo korzystnie dla planów Jana III. W Europie nie obawiano się zagrożenia osmańskiego. W Rzeczypospolitej zerwanie sejmu w 1681 roku uświadomiło Sobieskiemu, że nie może dopuścić, aby powtórzyło się to w przyszłości. Zaczął więc planować osłabienie stronnictwa francuskiego, które było zagrożeniem dla jego nowych zamierzeń. Wydarzenia z roku

56 Biblioteka Zakładu Narodowego im. Ossolińskich we Wrocławiu, Teka Lukasa 2999, s. 16-17. „Cała izba radośnie gratulowała”, mimo że wcześniej łajano posłów krakowskich, że Lubomirski został obrany posłem.

57 J. Stolicki, Działania Jana III..., s. 38.

58 Skrypt ad archivum na sejmie w Grodnie dany względem wojny tureckiej, B. Czart TN 176, s. $387-389$.

59 J. Stolicki, Propaganda antyturecka w latach 1676-1683 [w:] Król Jan III Sobieski i Rzeczpospolita $w$ latach 1674-1683, red. D. Milewski, Warszawa 2016, s. 19-33. O działaniach w celu budowy ligi zob. K. Konarski, rozdz. V, VI. 
1683 pokazały dalekowzroczność Sobieskiego, który dzięki wcześniejszym doświadczeniom skutecznie przeprowadził swe zamysły. Kryzys wewnętrzny Rzeczypospolitej, duże znaczenie fakcji magnackich oraz osłabienie pozycji i autorytetu monarchy po rokoszu Lubomirskiego zmusiły Sobieskiego do ostrożnego postępowania w sprawach wewnętrznych, a fiasko planów bałtyckich tylko go w tym utwierdziło. Wykorzystał wsparcie nuncjusza i zaskoczył przeciwników, odcinając się od niepopularnych działań. W dalszej kolejności musiał przekonać szlachtę o zagrożeniu tureckim i pozyskać jej zgodę na zawarcie antytureckiego przymierza z cesarzem. Wszystkie te plany zostały sprawnie przeprowadzone i leżały u źródeł zwycięstwa pod Wiedniem.

\section{BIBLIOGRAFIA}

\section{Źródła rękopiśmienne}

Archiwum PAN w Warszawie, Materiały Janusza Wolińskiego, teka 66.

Biblioteka Czartoryskich w Krakowie, Teki Naruszewicza 172, 176, rkps 423.

Biblioteka PAN w Kórniku, rkps 385.

Biblioteka PAU-PAN w Krakowie 1855; Teki Rzymskie 8431.

Biblioteka Zakładu Narodowego im. Ossolińskich we Wrocławiu, Teki Lukasa 2999.

\section{Źródła drukowane}

Akta sejmikowe województw poznańskiego i kaliskiego. Lata 1675-1695, wyd. M. Zwierzykowski, R. Kołodziej, A. Kamieński, Poznań 2019.

Akta sejmiku podolskiego in hostico 1672-1698, wyd. i oprac. J. Stolicki, Kraków 2002.

Pisma do wieku i spraw Jana Sobieskiego, wyd. F. Kluczycki, Kraków 1884.

Woliński J., Materiaty do dziejów wojny polsko-tureckiej 1672-1676, „Studia i Materiały do Historii Wojskowości”, t. XII, cz. II.

\section{Opracowania}

Barycz H., Rzecz o studiach w Krakowie dwóch generacji Sobieskich, Kraków 1984.

Hundert Z., Wojsko koronne a elekcja 1674 roku [w:] Wokót wolnych elekcji w państwie polsko-litewskim XVI-XVIII wieku, red. zbior., Katowice 2016, s. 308-332.

Kołodziej R., ,,Ostatni wolności naszej klejnot”. Sejm Rzeczypospolitej za panowania Jana III Sobieskiego, Poznań 2014.

Konarski K., Polska przed odsiecza wiedeńska r. 1683, Warszawa 1914.

Markiewicz M., Historia Polski 1492-1795, Kraków 2004. 
Matwijowski K., Czy Sobieski zamierzał dokonać absolutystycznego zamachu stanu [w:] Studia z dziejów epoki Jana III Sobieskiego, red. K. Matwijowski, Wrocław 1984, s. $75-87$.

Matwijowski K., Pierwsze sejmy z czasów Jana III Sobieskiego, Wrocław 1976.

Matwijowski K., [rec. Wójcik Z., Jan Sobieski 1629-1696, Warszawa 1983], „Śląski Kwartalnik Historyczny Sobótka” 1984, R. IXL, z. 1, s. 101-105.

Matwijowski K., Sejm grodzieński 1678-1679, Wrocław 1985.

Odsiecz Wiednia. Prace poświęcone trzechsetnej rocznicy zwycięstwa, Acta Universitatis Lodziensis, Folia Historica, 26, Łódź 1986.

Piwarski K., Hieronim Lubomirski hetman wielki koronny, Kraków 1929.

Przyboś A., Rożek M., Biskup krakowski Andrzej Trzebicki. Z dziejów kultury politycznej $i$ artystycznej $w$ XVII stuleciu, Warszawa-Kraków 1989.

Stolicki J., Biskupi krakowscy wobec polityki Jana III Sobieskiego [w:] Kościót Katolicki $w$ Małopolsce $w$ średniowieczu $i$ we wczesnym okresie nowożytnym, red. W. Kowalski, J. Muszyńska, Kielce 2001, s. 367-381.

Stolicki J., Działania Jana III w celu wzrostu znaczenia Rzeczypospolitej $w$ Europie w latach 1674-1683, „Studia Środkowoeuropejskie i Bałkanistyczne” 2017, t. XXV, red. I. Stawowy-Kawka, s. 27-41.

Stolicki J., Propaganda antyturecka w latach 1676-1683 [w:] Król Jan III Sobieski i Rzeczpospolita w latach 1674-1683, red. D. Milewski, Warszawa 2016, s. 19-33.

Stolicki J., Rozdawnictwo wakansów przez Jana III jako metoda tworzenia partii dworskiej [w:] Faworyci i opozycjoniści. Król a elity polityczne w Rzeczypospolitej XV-XVIII wieku, red. M. Markiewicz, R. Skowron, Kraków 2006, s. 359-375.

Stolicki J., Wobec wolności i króla. Działalność polityczna szlachty ruskiej, ukrainnej i wotyńskiej w latach 1673-1683, Kraków 2007.

Wagner M., Wojna polsko-turecka w latach 1672-1676, t. II, Zabrze 2009.

Woliński J., Epilog elekcji 1674 r., „Rozprawy Wydziału Historyczno-Filozoficznego PAU” 1952, seria II, t. XLVI (nadbitka).

Woliński J., Z dziejów wojny i polityki w dobie Jana Sobieskiego, Warszawa 1960.

Wójcik Z., Jan Sobieski 1629-1696, Warszawa 1983.

Wójcik Z., Rozmowa ziemianina ze statysta, „Śląski Kwartalnik Historyczny Sobótka” 1975, R. XXX, s. 321-333.

Wójcik Z., Rzeczpospolita wobec Turcji i Rosji 1674-1679, Wrocław 1976. 